\title{
Xenorhabdus gen. nov., a Genus of Entomopathogenic, Nematophilic Bacteria of the Family Enterobacteriaceae
}

\author{
GERARD M. THOMAS AND GEORGE O. POINAR, JR. \\ Division of Entomology and Parasitology, University of California, Berkeley, California 94720
}

\begin{abstract}
A new genus, Xenorhabdus, is created to accommodate large, gram-negative, rod-shaped, facultatively anaerobic, entomopathogenic bacteria which are intimately associated with entomogenous nematodes. The normal habitat of these bacteria is the intestinal lumen of nematodes or the body cavity of host insects into which they have been introduced by the nematodes. The genus is placed in the family Enterobacteriaceae since the bacteria possess most of the important characteristics of this family. Xenorhabdus differs from other genera of Enterobacteriaceae in large cell size, failure to reduce nitrates to nitrites, intimate association with entomogenous nematodes, entomopathogenesis, and immunological characteristics. The type species is Xenorhabdus nematophilus (Poinar and Thomas) comb. nov. (synonym: Achromobacter nematophilus Poinar and Thomas). Xenorhabdus luminescens sp. nov., a bioluminescent, entomopathogenic bacterium isolated from the intestinal lumen of an entomogenous nematode, Heterorhabditis bacteriophora, is also described. In addition to their immunological differences, the two species are dissimilar in that $X$. luminescens is positive for bioluminescence and catalase activity, whereas $X$. nematophilus is not. The type strain of $X$. nematophilus is ATCC 19061, and that of $X$. luminescens is strain $\mathrm{Hb}$ (= ATCC 29999).
\end{abstract}

In 1965, we (9) published a description of the bacterium Achromobacter nematophilus Poinar and Thomas, which was found in association with strain DD-136 of the nematode Neoaplectana carpocapsae Weiser (8). Further studies demonstrated the importance of A. nematophilus in the reproduction and development of this entomogenous nematode (10). Subsequently it was shown that other geographic populations of $N$. carpocapsae also formed associations with identical or related bacteria (12). More recent studies $(6,11$; G. O. Poinar, Jr., G. M. Thomas, K. A. Nelson, and M. Haygood, Soil Biol. Biochem., in press) have shown similar associations between bacteria and entomogenous nematodes in the genus Heterorhabditis.

The proposed rejection of the genus Achromobacter by Hendrie et al. (5) in 1974 was accepted in Bergey's Manual of Determinative Bacteriology 8 th ed. (1). Species described as belonging to the genus Achromobacter were transferred either to the genus Alcaligenes or to other genera. Achromobacter nematophilus, however, could not be accommodated as a species either in the genus Alcaligenes or in any other recognized genus.

Then in December 1975, we received specimens of the entomogenous nematode Heterorhabditis bacteriophora Poinar collected from Heliothis punctigera Wall. in Brecon, Australia, by Dudley E. Pinnock. The nematodes were found to carry a specific bacterium (tentatively labeled strain $H b$ ) in the lumen of the intestine. Studies (11) showed the association between the $\mathrm{Hb}$ bacterium and the nematode to be similar to that between $A$. nematophilus and the nematode $N$. carpocapsae Weiser $(8,10)$. These studies also showed the bacterium to be bioluminescent. The luminescent properties were further studied (Poinar et al., in press). Although the cultural and biological characteristics of the bacterium were studied in detail, the organism remained unclassified.

Both $A$. nematophilus and strain $\mathrm{Hb}$ were subsequently studied in order to determine their taxonomic positions. The results of this study are reported here.

\section{MATERIALS AND METHODS}

Bacterial strains. The technique described by Poinar (8) was used to isolate specific nematophilic bacterial associates from the intestinal lumen of entomogenous nematodes of the genera Neoaplectana and Heterorhabditis. A total of nine isolates were studied; their sources and designations are given in Table 1.

Methods. Test cultures were incubated at room temperature $\left(24^{\circ} \mathrm{C}\right)$. Measurements of cells were made with 24 -h-old peptone water shake cultures ( $1 \%$ peptone and $0.5 \% \mathrm{NaCl}$ ). Colony characteristics were recorded from 24-h-old nutrient agar (NA) cultures and from 1- to 5-day-old tergitol-7 agar cultures with triphenyl-tetrazolium chloride (T-7+TTC agar) (3). Bio- 
TABLE 1. Designations and sources of the strains used in this study

\begin{tabular}{|c|c|c|}
\hline Strain & 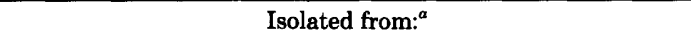 & Date of isolation \\
\hline $\begin{array}{l}\text { A. nematophilus } \\
\text { ATCC } 19061\end{array}$ & DD-136 strain of $N$. carpocapsae Weiser & 1964 \\
\hline$X-I I$ & Unidentified nematode in Poland & July 1969 \\
\hline$D N$ & N. bibionis collected in Denmark & July 1969 \\
\hline$A 11$ & $\begin{array}{l}\text { Vitacea polistiformis (Har.) infected with Neoplec- } \\
\text { tana sp. collected in Georgia }\end{array}$ & July 1977 \\
\hline$R$ & $\begin{array}{l}\text { Rhagoletis pomenella infected with Neoplectana sp. } \\
\text { collected in Massachusetts }\end{array}$ & July 1977 \\
\hline$H b$ (ATCC 29999) & $\begin{array}{l}\text { Heterorhabditis bacteriophora Poinar collected in } \\
\text { Australia }\end{array}$ & October 1976 \\
\hline $\mathrm{Hb}-\mathrm{B}$ & $\begin{array}{l}\text { Capnodis tenebricosa infected with a Heterorhabditis } \\
\text { sp. collected near Rome, Italy }\end{array}$ & November 1978 \\
\hline$H m$ & $\begin{array}{l}\text { Undetermined species of Heterorhabditis collected in } \\
\text { Tifton, Ga. }\end{array}$ & October 1976 \\
\hline NC-19 (ATCC 29304) & $\begin{array}{l}\text { Heterorhabditis heliothidis (Khan, Brooks, and } \\
\text { Hirschmann); isolated by Khan and Brooks }\end{array}$ & 1977 \\
\hline
\end{tabular}

${ }^{a}$ Unless stated otherwise, all isolations were made by Thomas and Poinar.

luminescence was determined by observing NA cultures for $20 \mathrm{~min}$ in total darkness. Motility broth consisted of $18.5 \mathrm{~g}$ of brain heart infusion plus $5.0 \mathrm{~g}$ of glucose per liter of water and was incubated for $18 \mathrm{~h}$. Flagellum staining was carried out by the method of Leifson (7). Catalase activity was determined by flooding colonies on NA with $10 \%$ hydrogen peroxide; oxidase activity was checked by flooding colonies on NA with $1 \%$ aqueous tetramethyl- $p$-phenylenediamine dihydrochloride plus $0.1 \%$ ascorbic acid. Cytochrome oxidase activity was determined by the method of Schaefer (13). Methods for the following tests were obtained from the Difco Manual, 9th ed. (3) and from Difco Supplementary Literature (4): Lipase, Loeffler blood serum, gelatin liquefaction, triple sugar iron agar, Simmons citrate, phenylalanine deaminase, indole production, nitrate reduction, methyl red, VogesProskauer, and KCN. Tests for starch hydrolysis, oxidation or fermentation (Leifson medium), arginine dihydrolase, and glutamic acid, lysine, and ornithine decarboxylases (Møllers method) were described by Cowan and Steel (2). Anaerobic cultures were incubated in a Torbal model AJ-2 jar filled with hydrogen. Media used were NA and thioglycolate agar, a prereduced medium. The latter contained the following, per liter: yeast extract, $5 \mathrm{~g}$; Casitone, $15 \mathrm{~g}$; L-cystine, 0.25 $\mathrm{g}$; sodium chloride, $2.5 \mathrm{~g}$; thioglycolic acid $0.3 \mathrm{ml}$; and agar, 1.5 g. Clostridium sporogenes, a strict anaerobe, was used as a biological check for anaerobic conditions. Mean cell sizes were determined from measurements of 50 randomly selected cells examined under phasecontrast microscopy in live unstained wet mounts. The method of Williamson and Wilkinson (14) was used to determine whether the cellular inclusions were polybetahydroxybutyrate.

Fermentation studies were conducted with $1 \%$ of each test carbohydrate in peptone water adjusted to pH 7.0 with $\mathrm{NaOH}$. Two indicators were used: bromothymol blue, sensitive to slight acid changes in $\mathrm{pH}$, and bromocresol purple, sensitive to stronger acidity. By using a double check on fermentative activity, reversals in $\mathrm{pH}$ of weakly buffered solutions could be detected. The carbohydrates tested included adonitol, arabinose, glucose, dulcitol, esculin, fructose, inositol, lactose, mannitol, melezitose, melibiose, raffinose, rhamnose, saccharose, salicin, sorbose, sucrose, trehalose, and xylose. These tests, with appropriate controls, were checked every $24 \mathrm{~h}$ for 7 days.

The guanine plus cytosine $(\mathrm{G}+\mathrm{C})$ contents of the deoxyribonucleic acids (DNAs) of $A$. nematophilus ATCC 19061 and strains $N C-19, H b$, and $H m$ were determined by Manley Mandel, University of Texas, Texas Medical Center, Houston, and those for strains $X-I I, D N, A 11, R$, and $H b-B$, were determined by Kenneth Nealson, Scripps Institute of Oceanography, La Jolla, Calif.

\section{RESULTS}

The colonial characteristics of all strains are presented in Table 2, and their morphological and biochemical characteristics are shown in Table 3 .

\section{DISCUSSION}

According to Bergey's Manual of Determinative Bacteriology 8th ed. (1), gram-negative, facultatively anaerobic rods fall into one of two families, the Enterobacteriaceae or the Vibrionaceae. It is doubtful that the bacteria described here can be accommodated in the Vibrionaceae, since they differ from this family in being oxidase negative and peritrichous. Membership in the Enterobacteriaceae seems more likely. Although these bacteria do not reduce nitrates to nitrites (as is also true of some Erwinia strains) and are generally catalase negative and anerogenic, they do possess the remaining characters of the family.

The isolates described here differ from the currently accepted genera in the family Enterobacteriaceae by their large cell size, their im- 
TABLE 2. Colonial characteristics of the strains studied ${ }^{a}$

\begin{tabular}{|c|c|c|}
\hline \multirow{2}{*}{ Strain } & \multicolumn{2}{|c|}{ Colonial characteristics on: } \\
\hline & NA & T-7+TTC agar \\
\hline A. nematophilus & About $1 \mathrm{~mm}$ in diameter; grayish white to & Gray at first, soon turning blue and darken- \\
\hline ATCC 19061 & $\begin{array}{l}\text { light buff; convex; circular; slightly irreg- } \\
\text { ular margins; somewhat granular in ap- } \\
\text { pearance. }\end{array}$ & $\begin{array}{l}\text { ing with age, developing deep maroon } \\
\text { centers; agar turns blue: clear zones de- } \\
\text { velop around colonies in } 3 \text { to } 5 \text { days. }\end{array}$ \\
\hline$A 11$ & $\begin{array}{l}\text { About } 1 \mathrm{~mm} \text { in diameter; grayish white to } \\
\text { light buff; convex; circular; slightly irreg- } \\
\text { ular margins; somewhat granular in ap- } \\
\text { pearance. }\end{array}$ & $\begin{array}{l}\text { Gray at first, soon turning blue and darken- } \\
\text { ing with age, developing deep dark blue } \\
\text { centers; agar turns blue; clear zones de- } \\
\text { velop around colonies in } 3 \text { to } 5 \text { days. }\end{array}$ \\
\hline$R$ & $\begin{array}{l}\text { About } 1 \mathrm{~mm} \text { in diameter; grayish at first, } \\
\text { soon turning buff-yellow-brown; convex; } \\
\text { circular; slightly irregular margins; some- } \\
\text { what granular in appearance. }\end{array}$ & $\begin{array}{l}\text { Gray at first, soon turning greenish, } \\
\text { darkening to blue-green with age, with } \\
\text { deep dark blue (purplish) centers; agar } \\
\text { turns blue; clear zones develop around } \\
\text { colonies in } 3 \text { to } 5 \text { days. }\end{array}$ \\
\hline$X-I I$ & $\begin{array}{l}\text { About } 1 \mathrm{~mm} \text { in diameter; yellow; convex; } \\
\text { circular; slightly irregular margins; some- } \\
\text { what granular in appearance. }\end{array}$ & $\begin{array}{l}\text { Gray at first, soon turning greenish blue; } \\
\text { agar turns blue; clear zones develop } \\
\text { around colonies in } 3 \text { to } 5 \text { days; yellow } \\
\text { crystals develop in agar under dense } \\
\text { growth. }\end{array}$ \\
\hline$D N$ & $\begin{array}{l}\text { About } 1 \mathrm{~mm} \text { in diameter; yellow; convex; } \\
\text { circular; slightly irregular margins; some- } \\
\text { what granular in appearance. }\end{array}$ & $\begin{array}{l}\text { Gray at first, soon turning greenish blue, } \\
\text { darkening with age; agar turns blue; clear } \\
\text { zones develop around colonies in } 3 \text { to } 5 \\
\text { days; yellow crystals develop in agar un- } \\
\text { der dense growth. }\end{array}$ \\
\hline$H b$ & $\begin{array}{l}\text { About } 1 \mathrm{~mm} \text { in diameter; light red-brown } \\
\text { at first, darkening with age to a rust } \\
\text { color; convex; circular; slightly irregular } \\
\text { margins; mucoid to somewhat granular } \\
\text { in appearance. }\end{array}$ & $\begin{array}{l}\text { Gray at first, soon turning greenish and } \\
\text { developing red-brown centers; agar turns } \\
\text { blue; clear zones develop around colonies } \\
\text { in } 3 \text { to } 5 \text { days. }\end{array}$ \\
\hline$H b-B$ & $\begin{array}{l}\text { About } 1 \mathrm{~mm} \text { in diameter; light red-brown } \\
\text { at first, darkening with age; convex; cir- } \\
\text { cular; slightly irregular margins; mucoid } \\
\text { to somewhat granular. }\end{array}$ & $\begin{array}{l}\text { Gray at first; soon turning greenish and } \\
\text { developing red-brown centers; agar turns } \\
\text { blue; clear zones develop around colonies } \\
\text { in } 3 \text { to } 5 \text { days. }\end{array}$ \\
\hline$H m$ & $\begin{array}{l}\text { About } 1 \mathrm{~mm} \text { in diameter; light buff-brown } \\
\text { at first, darkening with age to a light } \\
\text { brown; convex; circular; slightly irregular } \\
\text { margins; mucoid to somewhat granular } \\
\text { in appearance. }\end{array}$ & $\begin{array}{l}\text { Gray at first, soon turning green and de- } \\
\text { veloping red-brown centers; agar turns } \\
\text { blue; clear zones develop around colonies } \\
\text { in } 3 \text { to } 5 \text { days. }\end{array}$ \\
\hline NC-19 & $\begin{array}{l}\text { About } 1 \mathrm{~mm} \text { in diameter; cream-yellow at } \\
\text { first, turning pink-red to brick red with } \\
\text { age; convex; circular; slightly irregular } \\
\text { margins; highly mucoid. }\end{array}$ & $\begin{array}{l}\text { Gray at first, soon turning greenish, } \\
\text { darkening with age to a dull olive green; } \\
\text { agar turns blue; clear zones develop } \\
\text { around colonies in } 3 \text { to } 5 \text { days. }\end{array}$ \\
\hline
\end{tabular}

${ }^{a}$ Cultivation was for 1 to 5 days at room temperature $\left(24^{\circ} \mathrm{C}\right)$.

munological properties, their intimate association with entomogenous nematodes, and their pathogenesis for insects (Table 4). Consequently, they are here regarded as members of a new genus, for which the name Xenorhabdus is proposed. [Xe. no. rhab' dus. Gr. noun xenos unwanted guest (pathogen); Gr. noun rhabdus (rod-shaped bacterium associated with rhabditoid nematodes in the superfamily Rhabditoidea); M.L. masc. noun Xenorhabdus pathogenic rod associated with rhabditoid nematodes.]

The characters of this new genus are described below.
Xenorhabdus gen. nov. Gram-negative, asporogenous, peritrichous rods measuring approximately 0.8 to 2.0 by 4.0 to $10.0 \mu \mathrm{m}$. Motile. In older cultures, crystalline inclusions (which are not polybetahydroxybutyrate) are formed within cells; spherical cells, resulting from the disintegration of the cell wall, average $2.6 \mu \mathrm{m}$ in diameter. Facultatively anaerobic. Nutrition is chemoorganotrophic; good growth occurs on meat extract and on simple peptone agar. Metabolism is respiratory and fermentative. Acid, usually without gas, is produced from the fermentation of glucose and other carbohydrates (all carbohydrates tested gave positive to weakly 
positive results). Starch is not hydrolyzed.

Colonies on nutrient agar are about $1 \mathrm{~mm}$ in diameter in 24 to $48 \mathrm{~h}$ at $24^{\circ} \mathrm{C}$; they may be smooth, moist, and somewhat granular in appearance, although mucoid forms occur; low convex; circular; margins are slightly irregular, grayish, cream-colored, yellowish brown, red, or rust brown to reddish; may or may not exhibit bioluminescence.

Young colonies (24- to 48-h-old) on T-7+TTC agar are gray, but as the colonies age, bromothymol blue is absorbed from the medium and combines with pigments produced by the bacteria, causing the colonies to take on a characteristic coloration ranging from blue to shades of green and greenish blue. The reaction is alkaline, and the medium turns blue.

Glutamic acid decarboxylase is produced. Lysine and ornithine decarboxylases, arginine dihydrolase, phenylalanine deaminase, urease, oxidase, and cytochrome oxidase are not produced. The methyl red and Voges-Proskauer tests are negative. Indole and $\mathrm{H}_{2} \mathrm{~S}$ (triple sugar iron agar) are not produced. Nitrates are not reduced to nitrites.

Lipase is generally not produced. Citrate is generally not utilized. Members of the genus may or may not be proteolytic (Loeffler blood serum and nutrient gelatin). Catalase may or may not be produced, but even apparently negative strains may occasionally show weakly positive results.

The $\mathrm{G}+\mathrm{C}$ content of the DNA is 43 to 44 $\mathrm{mol} \%$. Immunologically distinct from the marine luminescent bacteria, as well as from members of the genera Escherichia, Enterobacter, Serratia, Proteus, and Aeromonas (Paul Baumann, personal communication).

The natural habitat for these bacteria is the intestinal lumen of entomogenous nematodes and the body cavity of infected host insects.

The type species is Xenorhabdus nematophilus (Poinar and Thomas) comb. nov.

The nine strains included in this study are divided into two species, mainly on the characters of bioluminescence, catalase production, inhibition of growth by KCN, and genus of associated nematode. The nonluminescent strains (A. nematophilus ATCC 19061, A11, R, X-II, and $D N)$ are associated with nematodes in the genus Neoaplectana, and the luminescent strains $(\mathrm{Hb}, \mathrm{Hb}-\mathrm{B}, \mathrm{Hm}$, and $\mathrm{NC}-19)$ are associated with nematodes in the genus Heterorhab. ditis. The species are described as follows.

Xenorhabdus nematophilus (Poinar and Thomas) comb. nov. (basionym: Achromobacter nematophilus Poinar and Thomas.)

Large, gram-negative, asporogenous, motile, peritrichous rods (Fig. 1A), measuring 5.4 to 9.4 by 1.0 to $1.7 \mu \mathrm{m}$. In older cultures crystalline inclusions are formed within the cells, and spherical cells from 2.4 to $3.7 \mu \mathrm{m}$ in diameter are formed due to the disintegration of the cell wall. Facultatively anaerobic. Metabolism is respiratory and fermentative. Nutrition is chemoorganotrophic, and good growth is produced on meat extract media and simple peptone agar. Not bioluminescent.

Colonies on NA are about $1 \mathrm{~mm}$ in diameter in 24 to $48 \mathrm{~h}$ at $24^{\circ} \mathrm{C}$; smooth, moist, and somewhat granular in appearance; low convex; circular; with slightly irregular margins; and cream colored (two strains), yellow-brown (one strain), or yellow (two strains).

On T-7+TTC agar, colonies gradually develop a characteristic color blue with maroon centers (two strains) or blue-green with dark blue centers (three strains). All strains develop clearing zones around the colonies.

The five strains studied produce acid, but no gas, from the fermatation of glucose and other carbohydrates (Table 4). Starch is not hydrolyzed.

Litmus milk is reduced and peptonized by the five strains; one stain produces a curd. All of the strains are proteolytic and produce brown pigment on Loeffler blood serum. Gelatin is liquefied by three of the five strains. The pigment produced on potato slants is buff (two strains), brown (one strain), or orange (two strains). Growth is not inhibited by KCN. Hydrogen sulfide is not produced.

The five strains produce glutamic acid decarboxylase, but catalase, oxidase, cytochrome oxidase, lipase, urease, phenylalanine deaminase, arginine dihydrolase, lysine decarboxylase, and ornithine decarboxylase are not produced. Indole is not produced, and nitrate is not reduced to nitrite. The five strains are negative for the methyl red test and the Voges-Proskauer reaction.

The $\mathrm{G}+\mathrm{C}$ content of the DNA is 43.0 to 43.5 $\mathrm{mol} \%$.

The natural habitat is in the instestinal lumen of nematodes in the genus Neoaplectana.

The type strain is ATCC 19061 (9). Additional strains of this species described in this paper are $A 11, R, X-I I$, and $D N$.

Xenorhabdus luminescens sp. nov. (lu.mi.nes'cens. M.L. v. luminesco luminesce; M.L. pres. part. luminescens luminescing.)

Large, gram-negative, asporogenous, motile, peritrichous rods (Fig. 1B), measuring 5.1 to 6.0 by 0.8 to $1.4 \mu \mathrm{m}$. In older cultures crystalline inclusions are formed within the cells, and spherical cells from 2.4 to $2.6 \mu \mathrm{m}$ in diameter are formed due to the disintegration of the cell wall. Facultatively anaerobic. Metabolism is respira- 


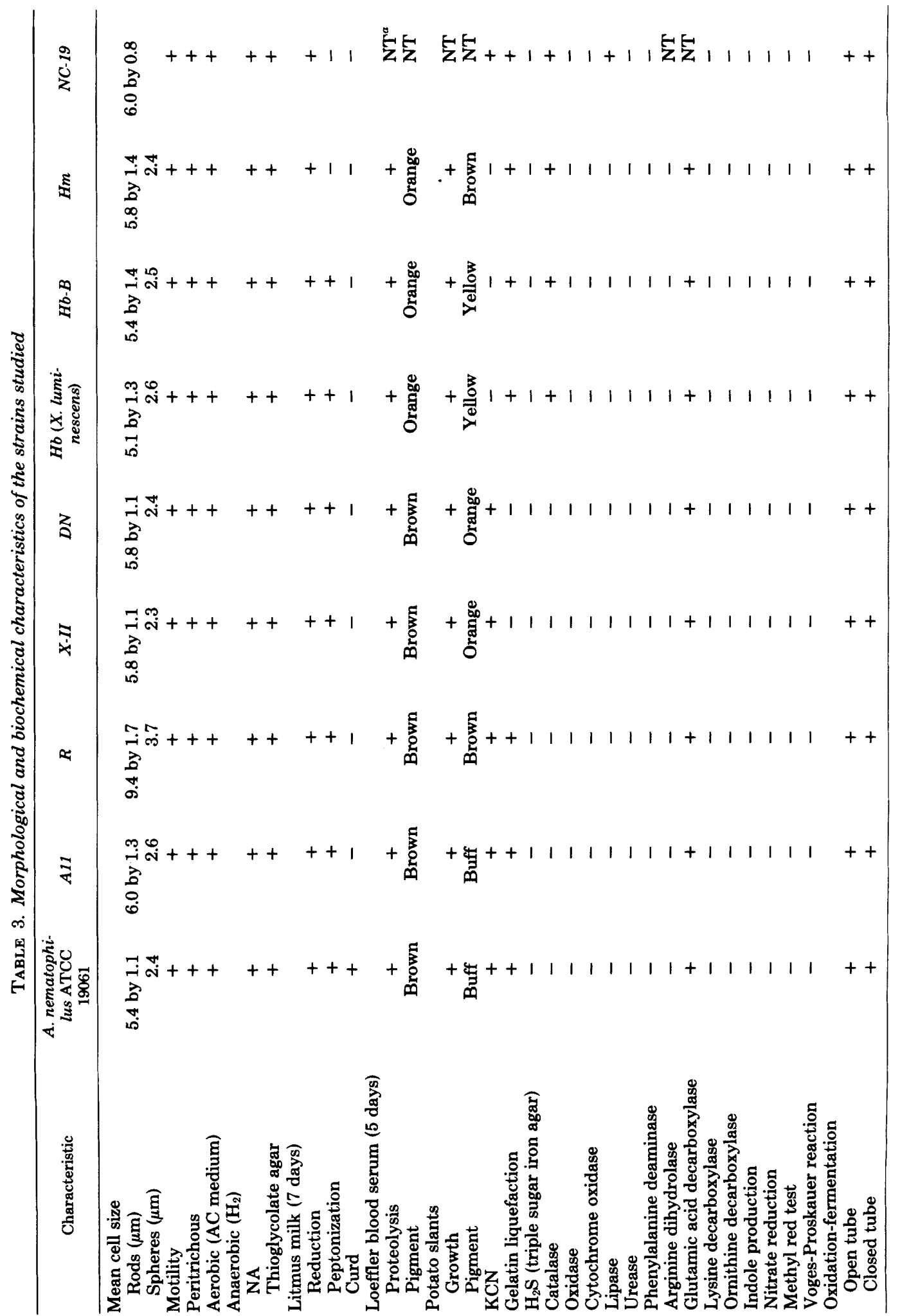




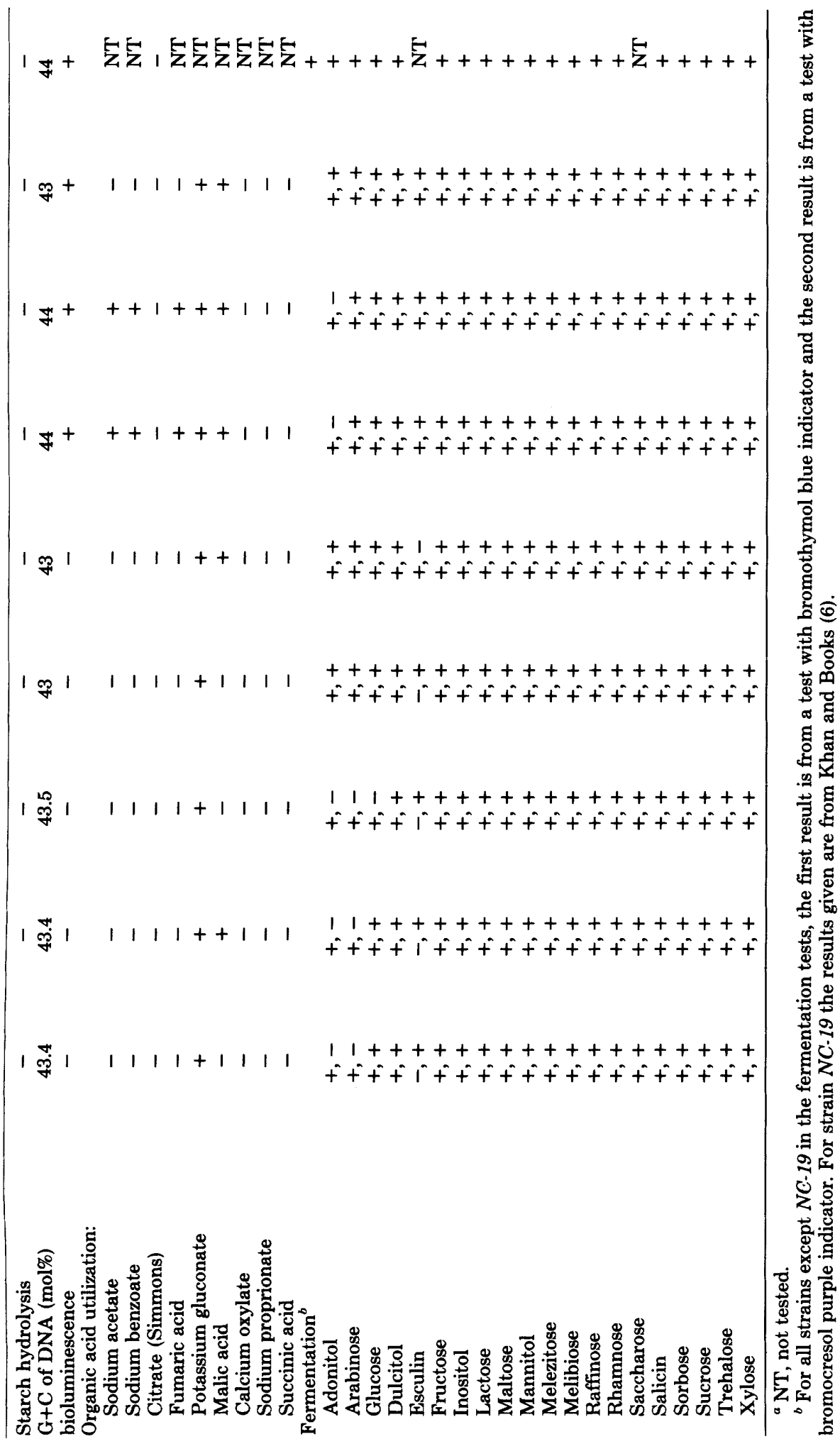




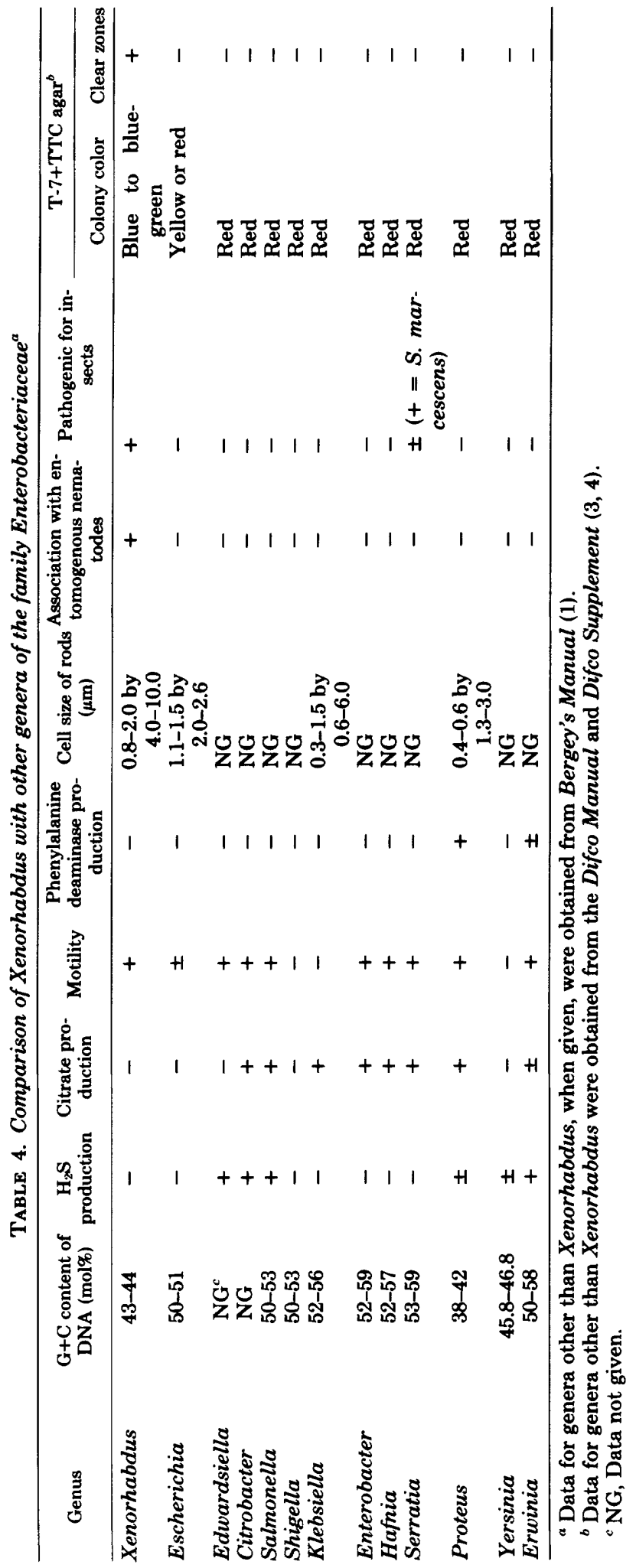



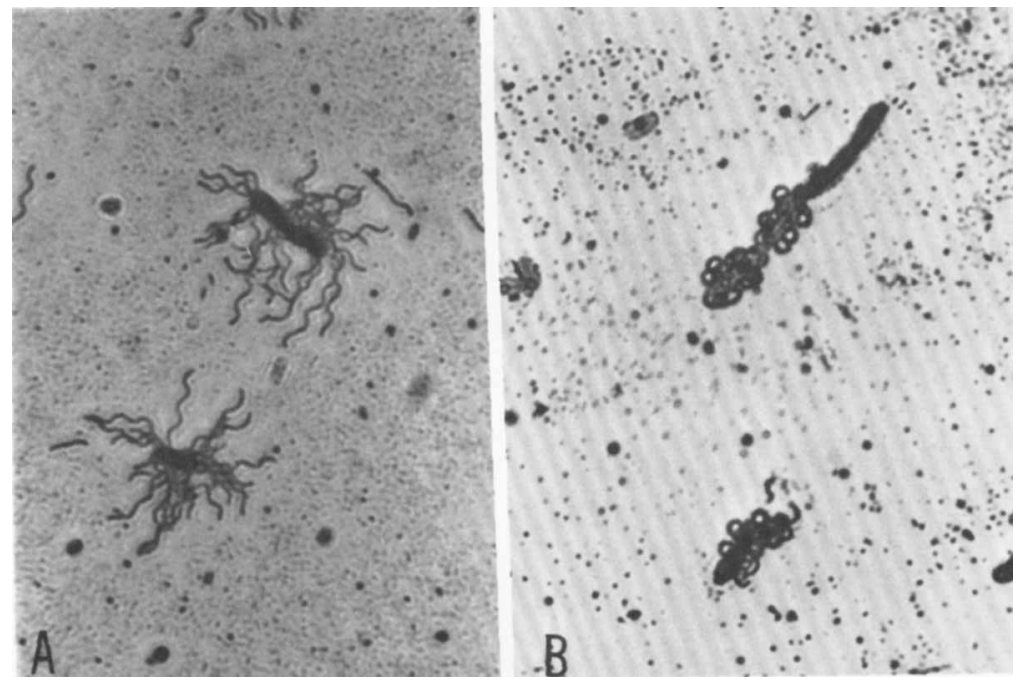

Frg. 1. Bacterial cells stained by the Leifson method for flagella, demonstrating the peritrichous cells of $X$. nematophilus $(A)$ and $X$. luminescens $(B)$.

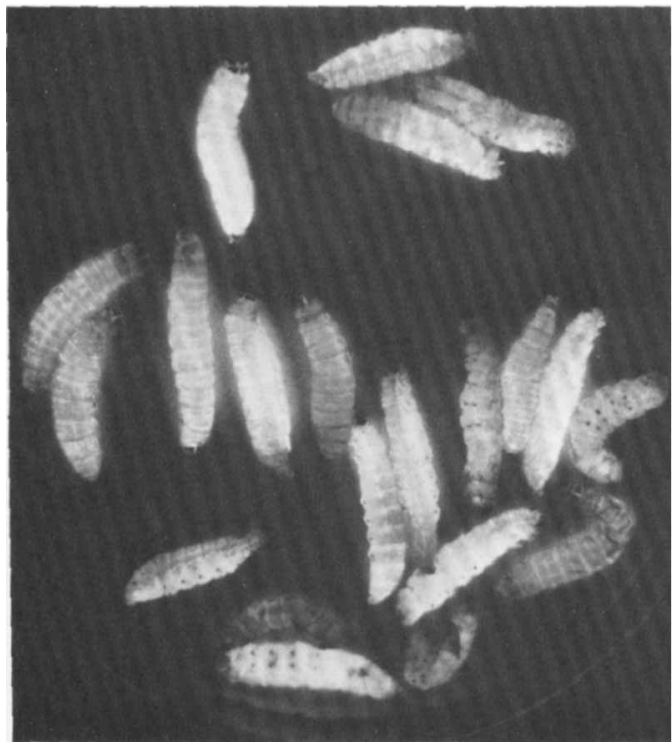

FIG. 2. Photograph of Galleria mellonella L. larvae infected with $X$. luminescens. Photographed in darkness to show the light emitted from the infected insects.

tory and fermentative. Nutrition is chemoorganotrophic, and good growth is produced on meat extract media and simple peptone agar. Bioluminescent. Luminescence has been observed on NA, on T-7+TTC agar, in nutrient broth, in peptone water, and in infected insects (Fig. 2).

Colonies on NA are about $1 \mathrm{~mm}$ in diameter in 24 to $48 \mathrm{~h}$ at $24^{\circ} \mathrm{C}$; smooth, somewhat granular to mucoid (three strains) or highly mucoid (one strain) in appearance; low convex; circular; with slightly irregular margins; brown (one strain), rust brown (two strains), or brick red (one strain).

Colonies on T-7+TTC agar gradually develop a characteristic color, greenish with red-brown centers (three strains) or dull olive green (one strain). All strains develop clear zones around the colonies.

The four strains studied produce acid, but not gas, from the fermentation of glucose and other carbohydrates (Table 4). Starch is not hydrolyzed.

In litmus milk, reduction takes place for four strains, and peptonization takes place for two strains; none of the strains produces curd. One strain (NC-19) was not tested on Loeffler blood serum or potato slants. The other three strains are proteolytic and produce orange pigment on Loeffler blood serum and yellow pigment (two strains) or brown pigment (one strain) on potato slants. Growth is inhibited by KCN in three of the strains but not in the fourth. Hydrogen sulfide is not produced.

The four strains produce catalase. Three strains produce glutamic acid decarboxylase; the fourth strain ( $N C-19)$ was not tested. Oxidase, cytochrome oxidase, lipase, urease, phenylalanine deaminase, arginine dihydrolase, lysine decarboxylase, and ornithine decarboxylase are not produced. Indole is not produced, and nitrate is not reduced to nitrite. The four strains are neg- 
ative for the methyl red test and the VogesProskauer reaction.

The $\mathrm{G}+\mathrm{C}$ content of the DNA is 43.0 to 44.0 mol\%.

The natural habitat is in the intestinal lumen of nematodes in the genus Heterorhabditis. In addition, immunological studies conducted by Paul Bauman, University of California at Davis, indicate that $X$. luminescens is distinct from $X$. nematophilus and that $X$. luminescens is also distinct from the marine bioluminescent bacteria.

The type strain is strain $H b$ (=ATCC 29999). Additional strains of this species described in this paper are $H b-B, H m$, and $N C-19$ (=ATCC 29304).

\section{ACKNOWLEDGMENTS}

We acknowledge with thanks the help of Manley Mandel, University of Texas, and Kenneth Nealson, Scripps Institute of Oceanography, for determining the $\mathrm{G}+\mathrm{C}$ contents of the DNAs and the help of Paul Baumann, University of California at Davis, for conducting the immunological studies on the strains.

\section{REPRINT REQUESTS}

Address reprint requests to: Gerard M. Thomas, $333 \mathrm{Hil}-$ gard Hall, Entomology and Parasitology, University of California, Berkeley, CA 94720.

\section{LITERATURE CITED}

1. Buchanan, R. E., and N. E. Gibbons (ed.). 1974. Bergey's manual of determinative bacteriology. 8 th ed. The Williams \& Wilkins Co., Baltimore.

2. Cowan, S. T., and K. J. Steel. 1966. Manual for the identification of medical bacteria. Cambridge University Press, New York.

3. Difco Laboratories. 1953. Difco manual of dehyrated cultural media and reagents for microbiological and clinical laboratory procedures, 9th ed. Difco Laboratories, Detroit, Mich.

4. Difeo Laboratories. 1962. Difco supplementary literature. Difco Laboratories, Detroit, Mich.

5. Hendrie, M. S., A. J. Holding, and J. M. Shewan. 1974. Emended descriptions of the genus Alcaligenes and of Alcaligenes faecalis and proposal that the generic name Achromobacter be rejected; status of the named species of Alcaligenes and Achromobacter. Int. J. Syst. Bacteriol. 24:534-550.

6. Khan, A., and W. M. Brooks. 1977. A chromogenic bioluminescent bacterium associated with the entomophilic nematode Chromonema heliothidis. J. Invert. Pathol. 24:253-261.

7. Leifson, E. 1960 . Atlas of bacterial flagellation. Academic Press, Inc., New York.

8. Poinar, G. O., Jr. 1966. The presence of Achromobacter nematophilus in the infective stage of a Neoaplectana sp. (Steinernematidae: Nematoda). Nematologica 12: 105-108.

9. Poinar, G. O., Jr. and G. M. Thomas. 1965. A new bacterium, Achromobacter nematophilus sp. nov. (Achromobacteriaceae; Eubacteriales) associated with a nematode. Int. Bull. Bacteriol. Nomencl. Taxon. 15: 249-252.

10. Poinar, G. O., Jr., and G. M. Thomas. 1966. Significance of Achromobacter nematophilus Poinar and Thomas (Achromobacteriaceae: Eubacteriales) in the development of the nematode, DD-136 (Neoaplectana sp. Steinernematidae). Parasitology 56:385-390.

11. Poinar, G. O., Jr., G. M. Thomas, and R. Hess. 1977. Characterization of the specific bacterium associated with Heterorhabditis bacteriophora Poinar (Heteror. habditidae; Rhabditida). Nematologica 23:97-112.

12. Poinar, G. O., Jr., G. M. Thomas, G. V. Veremtachuck, and D. E. Pinnock. 1971. Further characterization of Achromobacter nematophilus from American and Soviet populations of the nematode Neoaplectana carpocapsae Weiser. Int. J. Syst. Bacteriol. 21:78-82.

13. Schaefer, E. 1961. Application of the cytochrome oxidase reaction to the detection of Pseudomonas aeruginosa in mixed cultures. Roentgen Laboratoriumsprax. 14: 142-146.

14. Williamson, D. H., and J. F. Wilkinson. 1958. The isolation and estimation of the polybetahydroxybutyrate inclusions of Bacillus species. J. Gen. Microbiol. 19: 198-209. 